Trauma Fiction 



\section{Trauma Fiction}

Anne Whitehead

Edinburgh University Press 
(C) Anne Whitehead, 2004

Edinburgh University Press Ltd 22 George Square, Edinburgh

Typeset in Baskerville by Hewer Text Ltd, Edinburgh, and printed and bound in Great Britain by The Cromwell Press Ltd, Trowbridge, Wilts

A CIP record for this book is available from the British Library

ISBN 0748618570 (hardback)

The right of Anne Whitehead to be identified as author of this work has been asserted in accordance with the Copyright, Designs and Patents Act 1988. 